\title{
A Review of House of Debt
}

\author{
Dan-Qi ZHAO ${ }^{1, a}$ \\ ${ }^{1}$ Shanghai World Foreign Language Middle School, Shanghai 200233,China \\ aHelen-zdq@hotmail.com
}

Keywords: Household Debt, Leverage Ratio, The Great Depression

\begin{abstract}
The Subprime Mortgage Crisis in the United States is a financial crisis arising from the decline of housing prices and the subsequent collapse of the housing bubble, leading to the 20072009 U.S. recession and sweeping through the global financial market. In the book House of Debt: How They (and You) Caused the Great Recession, and How We Can Prevent It from Happening Again, the authors, Atif Mian and Amir Sufi, examine the primary cause of the financial crisis the expanding mortgage-backed security - and its chain effects on the local and national economic and social condition. The book offers valuable explanations of the crisis and possible solutions to the problem, backed up by sufficient evidence. The theory proposed by the book is also used to examine and evaluate the situation of housing industry in China.
\end{abstract}

\section{Introduction}

Atif Mian and Amir Sufi are leading scholars of economics in America, both of whom took part in the research and publication of the book. Mian is the the Theodore A. Wells '29 Professor of Economics and Public Affairs at Princeton University, and Sufi works as the Bruce Lindsay Professor of Economics and Public Policy at the University of Chicago Booth School of Business. Their coauthored House of Debt has gained great recognition, become the Financial Times Business Book Of The Year, and won The Gordon J. Laing Prize of the University of Chicago Press.

The book provides a full explanation of the financial crisis, starting from the rising of MBS. Mortgage-backed security caused an increasing demand for and purchase of houses with loans by economically vulnerable marginal consumers, raising housing bubbles, which collapsed later as bubbles greatly exceeded the real housing prices. Subsequently, consumer expenditure declined and recession emerged, followed and worsened by increasing unemployment. The book places a great emphasis on the "marginal borrowers", who are mainly families with low income levels and low leverage rate and are the group mostly affected by the real estate crisis. The pioneering theory is backed up by a complete logic link and plentiful data collected throughout the country over 10 years.

This paper is to summarize the theories and logic links proposed by the book (Section $2 \& 3$ ), evaluate the book in terms of methodology and feasibility (Section 4), and include a real-world case where the housing industries of China and America are to be examined and compared (Section 5).

\section{How did Housing Debt Cause the Great Recession?}

Research data have shown that before the financial crisis, there was a stark increase in the level of household indebtedness, the trigger point being a stark, sudden decline of household consumption expenses. The authors, Atif Mian and Amir Sufi, believe that a series of economic activities caused the 2008 subprime mortgage crisis. The rising demand for Mortgage-Backed Security boosted the credit expansion since 2000, which resulted in real estate bubbles, a hidden trigger of falling house prices. Meanwhile, credit expansion raised level of indebtedness in low-networth families. They cut consumption expenses during falling house prices, aggravating economic contraction. The basic theory of the book is as follows.

\section{The Rising of MBS and the subsequent Credit Expansion}

Since the Asian financial crisis in 1997, countries worldwide have been raising their demand for foreign exchange, generating an increasing amount of investment from foreign countries. This, 
together with a higher capital turnover, caused larger asset securitization , and thus greater amount of MBS among American banks. However, people were over-optimistic during the risk evaluation of MBS and neglected loopholes of the appraisal system, causing large amounts of character loans to be distributed among marginal borrowers with relatively low credit ratings. According to the research, the amount of residential mortgage loan rose annually by $30 \%$ in low-rating regions from 2002 to 2005, while that in higher-rating regions only rose annually by $11 \%$. The authors also point out that this credit expansion was not driven by fundamental growth of the economy, for it was accompanied by a fall in average household income and was not caused by increases in people's purchasing power.

\section{The Ramification of Credit Expansion: Real Estate Bubbles}

Credit expansion, together with people's false optimism towards the future, boosted real estate bubbles and further drove the housing price to increase continually. The real estate industry collapsed when people started to sell houses and cash out to pay off debts, the ensuing consequence being a long-term, drastic fall in housing price levels. This gave rise to two major negative impacts to the society. First, falling housing prices directly caused a loss in real values of low-net-worth families. The poor would thus be the biggest victims of the crisis. Second, to fill the gap of lost values of houses, banks started foreclosing on mortgages, resulting in a greater scale of decrease in housing prices; worse, it dragged the price level in the entire region, or even state, down. These ramifications synergised to aggravate the economic condition within regions. These are to be discussed further in 2.3.

\section{Expenditure Contraction and Unemployment}

Following the fall in housing prices came a shrink in household consumption expenditures. The authors believe that compared to the direct loss of wealth, household indebtedness played a more crucial role in cutting consumption spendings through three major ways. First, credit expansion elevated housing prices and inflated the real estate industry with bubbles, which, after the explosion, triggered plummets in housing prices and direct loss of family net wealth. To deal with the quagmire, families had to lower their spendings and cut consumption budgets. Second, after the decline in housing prices, many families were faced with the pressure of residential mortgage loan. To pay the loan off, they had no choice but ti cut expenses in other sectors. Meanwhile, as borrowers pledged their houses for mortgage, falling prices of houses prevented them from repaying. To prevent further losses, banks engaged in foreclosure, but aggravated and stimulated further price decline, causing surrounding families to reduce expenditures as well.

Beside the direct causation of retrenchment, household indebtedness exacerbated the impacts of housing price decline. To explain this, the authors introduce the notion of "Leverage framework", which underlies two major influences of the great collapse. First of all, debts caused marginal borrowers with low leverage rates to be exposed under the harm. This was because the savings of the rich was converted to the loans of the poor. Thus, the rich had not only higher, more diverse net value assets, but also the first-hand ownership to the pledged houses. Conversely, the poor suffered from not only losses in wealth, but also more severe indebtedness. In the light of this instance, debts widened the rich-poor gap and divided the people. Meanwhile, a corresponding consumption shrink was also seen in indebted families. These two impacts induced the greatest harm to the most vulnerable group of people during financial crisis and augmented the attack from falling house prices.

In real world, when combating the harsh retrenchment in 2008, banks commonly took the expansionary monetary policy, reducing interest rates, injecting cash, encouraging borrowing and spendings, and boosting purchasing powers. However, interest rates faced Zero Lower Bound, which constrained the economy into a liquidity trap. Even though interest rate reached its lowest, which was $0 \%$, the expenditure gap caused by retrenchment was still not filled, and the cash failed to flow along the economic cycle. People would rather save the money with them than to spend them for consumption. This major friction made monetary policy ineffective, and thus continued people's falling demand for goods and services. 
The fall in demand of goods and services was a big threat to the economic recession, for it caused large-scale unemployment nationwide. Though the initial impact of falling housing prices was only seen in particular regions, the local tradable jobs (or jobs that link with other regions and serve for the national economy) were also subject to a loss in production and profits. The pressure and harm would soon be transferred to other regions when connected positions were infected with the "disease". Real-world cases showed even worse results than predicted. The wages for workers did not fall, and most workers refused to move to places with more jobs. In other words, firms continuously laid off workers, who were reluctant to move and would rather stay unemployed. These were two other frictions that prevented the economy from recovering after the 2008 great financial disaster.

\section{Suggested solutions to the financial crisis}

After the serial disasters of the 2008 financial crisis, the American government and central bank issued higher amounts of reserves to other business banks and institutions, as banks function as payment intermediaries, credit intermediaries, and have political influences. However, this action is denied by the authors, who believe that instead of banks, households under debts should be the ones to be saved in the first place. Specifically, they speak of debt relief and debt restructuring, which both aim at reducing debts for marginal debtors who were financially impaired during the crisis and splitting debts between creditors and borrowers.

Two other common measures taken by the government are inflationary monetary and fiscal policies, but neither was very effective. Federal Reserve System doesn't directly control currency, and can only control money supply through adjusting interest rates and encouraging borrowing, which people were not willing to do so as they had just gone through the crisis. On the other hand, as the fundamental problem of the crisis were debts, fiscal policy is not as effective as debt relief either.

Admittedly, moral hazard should be a concern and might arise from government intervention. However, it is argued that house buyers were not likely to commit moral hazards as housing prices fell far beyond people's expectation and control. In this sense, debt restructuring is still a desirable measure.

Moreover, the authors believe that apportionment of liability should be included into pledge agreement in order to make the agreement more elastic and adjustable. A liability residential pledge agreement has many advantages over the previous mortgage issues in that it could protect borrowers in case of depreciation, provide incentives in the economy, protect employment rate, and prevent bubbles from growing.

\section{Evaluation}

The book is notable in that it makes a breakthrough in explaining the cause of the financial crisis and presenting the whole chain reaction. It has always been known that the cause of depression was deregulation of the financial industry, but the authors specify the problem down to debts. They trace the debts problem back to the 1990s and explain the whole process of MBS boom; consequently, house prices and bubbles emerged together with the debts until the 2008 collapse of the entire housing industry and debt system. Another highlight of the book lies in its explanation of the causation of debt crisis and household consequences like retrenchment and unemployment. Specifically, they focus on the marginal borrowers, poor families who were the most economically vulnerable group in the society yet the most crucial group during the financial crisis, their conditions amplifying the impact.

Moreover, in their argument, the authors counter other prevalent theories with sufficient data. While discussing the relationship between increasing debt and rising housing prices, they rebutted the "Animal Spirits" theory, which claims that people's increasing will to purchase houses drives housing prices up. Instead, they introduced the notion of housing elasticity and analyzed relevant 
data to prove that all housing bubbles were "debt-centered". This has made the book more valuable by presenting a clearer and more real chain impact.

During the argumentation, one of the biggest highlights is its detailed study and analysis of various regions according to their credit ratings. The authors also pay close attention to the conditions and data of marginal borrowers, which their whole argument is based on. These two entry points make the argument innovative. In the data collection, regions are differentiated by zip codes, a potent representative of the areas with different residents groups. This is a useful tool for the study as families of similar financial conditions often group together.

A potential problem of the book, however, lies in the suggested policy. While the authors give strong reasons to argue for debt relief, there's a probability that the measure is infeasible or may lead to undesirable ramifications. If the pledge agreement was set elastic and the debt was split based on liability, some borrowers would ask for more loans, disregarding the potential risk of debts, raising the leverage rate. They would take the debt relief as an incentive to encourage borrowing. However, if they take actions before consideration, a financial turmoil may emerge when too much debt is loaded but nobody expects to pay for the risk.

\section{Real World Case}

The theory presented by the book draws great attention to household indebtedness and consumer expenditure in America, rendering a potential indicator of housing bubbles in other countries of the world. In this case, China is to be examined based on its household mortgages and household spending using household leverage ratio. This is measured by the percentage of household debts to nominal GDP in China. All data are extracted from the Bank for International Settlement. The leverage ratios in household sector in China through 11 years (from the first quarter of 2006 to the second quarter of 2017) form the following trend:

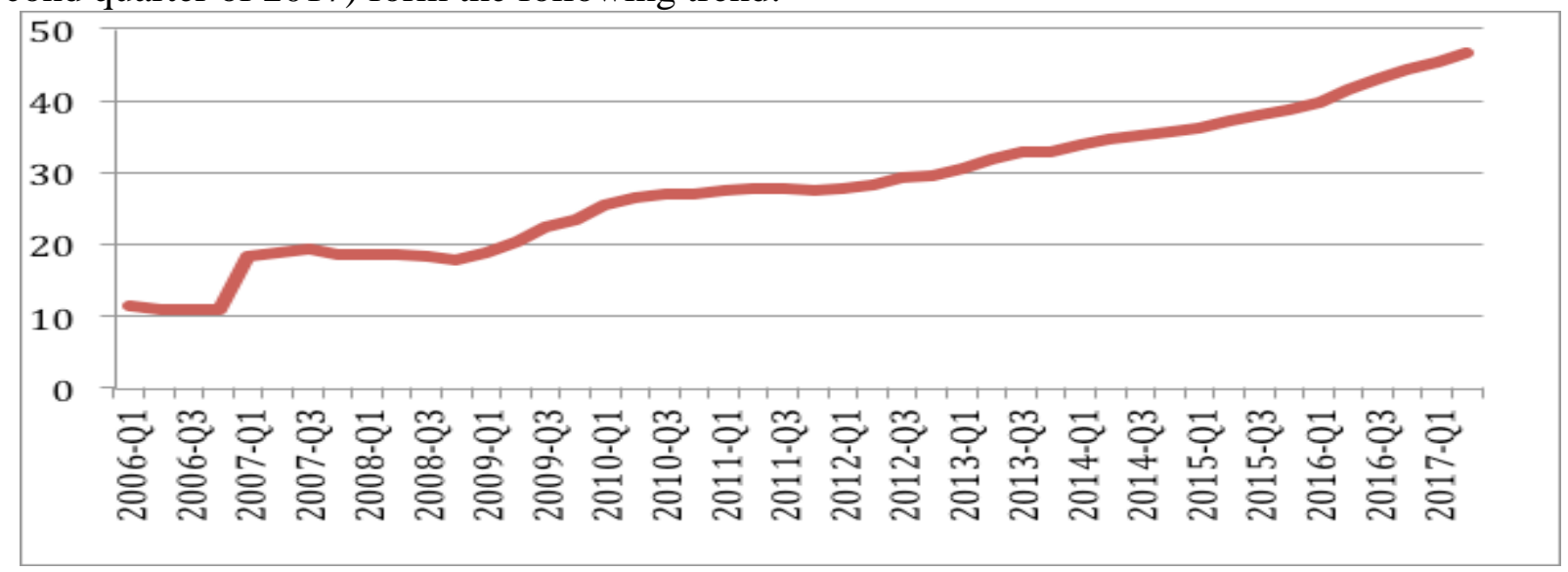

Fig. 1 The Leverage Ratio in Household Sector in China from 2006 Q1 to 2017 Q2

The amount of debts was relatively low in early 2006, at only $11.5 \%$ of the total nominal GDP, which was 21 trillion RMB back then. In 2006 the debts remained stable at 10 to 11\%. From 2007, however, the leverage ratio started to raise rigorously together with the uplifting GDP. Housing prices, meanwhile, was also soaring; real estate prices in urban areas, especially eastern coasts, have grown by an annually $20 \%$ or more, according to ForeignPolicy 1 . In the past ten years, the leverage ratio has bee lifted up to $46 \%$ and ready to approach $50 \%$. This indicates a sharp increase in household indebtedness of Chinese people. Within the same time period, compare the leverage ratio of China with that of the United States: 


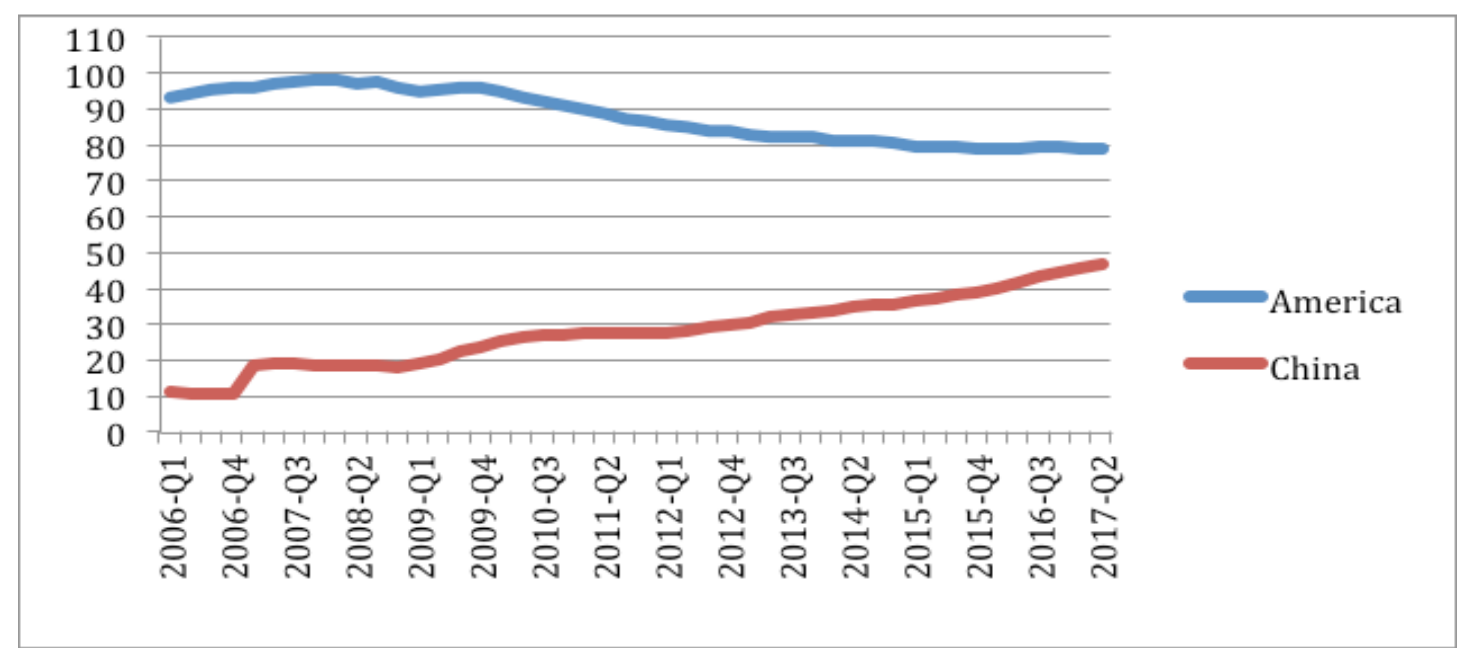

Fig.2 The Leverage Ratio in Household Sector in China and the USA from 2006 Q1 to 2017 Q

The households in United States have remained in high indebtedness since 2006; though in 2008 the index went up by $2-3 \%$, the ratio declined and became stable around $75 \%$. It does not show clear sign of future increase or decrease. China's leverage, on the contrary, is constantly rising and approaching that of the United States. As housing loans take the largest proportion of the leverage of Chinese households, and urban residents are the people who have the largest demand for houses, it can be deduced that urban households (especially those in first-and-second-tier cities) are having high levels of leverage. Therefore, even though Chinese households are having lower leverage ratios than Americans, they are under heavy burdens of loans as well.

To examine people's ability to pay back for the loans, take Beijing and New York City as an example. However, comparatively, Chinese are less able to pay back the loans. Take Beijing and New York City as an example. To compare the burden of debts of citizens in both cities, a ratio of house price to income is to be calculated. It measures the fraction of the price of a 100-square-meter residence to the annual disposable income per capita; the higher the ratio is, the greater the indebtedness of residents is likely to be. In 2016, average housing price per square meter is 50,583 RMB in Beijing, while citizens there hold an average income of 52,530 RMB. In New York City, the housing price in 2016 was $\$ 1,526$ per square foot, and average disposable income was \$49,251. Through calculation, it is found that the fraction of a $100 \mathrm{sqm}$ house in Beijing is 96.29 times of the annual income per capita, while the same residence accounts for 33.34 times of New Yorkers' income.

Therefore, Beijing citizens face an approximately three-times-higher burden in terms of house debts than New Yorkers; they also have a lower ability to pay back the loans due to their limited income. When people find themselves unable to repay the loans, household expenditure may decline together with bubble collapse as a result, triggering a potential financial crisis. Therefore, the income gap should alert the Chinese authority to take heed of growth trend in leverage ratio and to prevent it from skyrocketing. Regulations should also be implemented to forestall further growth in capital bubbles. With the high household indebtedness yet low personal income, the prevention of debt crisis is crucial for a healthy economy in China.

\section{References}

[1] Mian, A., Sufi, A., \& Verner, E. (2017). Household debt and business cycles worldwide. The Quarterly Journal of Economics, 132(4), 1755-1817.

[2] Mian, A., \& Sufi, A. (2017). The Macroeconomic Advantages of Softening Debt Contracts. Harv. L. \& Pol'y Rev., 11, 11.

[3] Mian, A., \& Sufi, A. (2015). House of debt: How they (and you) caused the Great Recession, and how we can prevent it from happening again. University of Chicago Press. 
[4] Mian, A., Sufi, A., \& Trebbi, F. (2014). Resolving debt overhang: political constraints in the aftermath of financial crises. American Economic Journal: Macroeconomics, 6(2), 1-28.

[5] Mian, A., \& Sufi, A. (2011). Consumers and the Economy, Part II: Household Debt and the Weak US Recovery. FRBSF Economic Letter, 2.

[6] Mian, A., \& Sufi, A. (2011). Household leverage and the recession of 2007 to 2009. SBP Research Bulletin, 7, 125-173.

[7] Mian, A., \& Sufi, A. (2009). The consequences of mortgage credit expansion: Evidence from the US mortgage default crisis. The Quarterly Journal of Economics, 124(4), 1449-1496. 